\title{
IMPACT OF CUTS TO LEGAL AID - COMPARATIVE VIEW AND ECONOMIC PROSPECTS
}

\author{
Barbara Preložnjak *
}

\begin{abstract}
Legal aid system creates an opportunity for equal access to legal services especially for low-income citizens. If legal aid system is not sufficiently financially resourced, it can hardly provide fair, equal and meaningful access to justice. In this paper, author lays out the debate over the economic justification of legal aid system in an era of limited public resources and argues that legal services reach further than the clients served which have many positive economic impacts.
\end{abstract}

KEYWORDS: legal aid, financial sustainability, economic analysis

"Justice and costs cannot be pitted against one another: justice must be considered on its own terms and cost must be borne by the state that wishes to call itself just."

Zoe Williams

\section{INTRODUCTORY REMARKS **}

Access to justice is a fundamental human right. It provides a legitimate claim on the government to secure services necessary to make human rights effective. Without equal access to justice other social rights become illusory and the

\footnotetext{
Assistant Professor at Department for Legal Theory, Faculty of Law, University of Zagreb; barbara.preloznjak@pravo.hr

** This paper is a result of scientific research done within the research project "New Croatian Legal System", Faculty of Law, University of Zagreb. It was also supported in part by Croatian Science Foundation in project "Transformation of Civil Justice under the Influence of Global and Regional Integration Processes. Unity and Diversity" no. 6988. The author would like to thank Professor A. Uzelac, Ph.D. and Assistant J. Brozović, Department for Civil Procedure, Faculty of Law, University of Zagreb, on constructive discussions on the topic of this work at the time of its emergence.
} 
most vulnerable people around the world are at high risk of having their rights ignored or violated. ${ }^{1}$ Therefore, access to legal aid is fundamental to ensure fair, equal and meaningful access to justice. ${ }^{2}$

Nowadays, the governments are having problems with provision of legal aid because too many people need it, but too few people are able to pay for it. ${ }^{3}$ Maintaining funding of legal aid services can be quite demanding for public budgets. Undoubtedly, governments are faced with difficult and often overlooked task of identifying legal aid system as an engine of equality, social justice and democratic empowerment. ${ }^{4}$ However, some efforts can be made against the negative impact that public budget cuts have on the legal aid systems.

Economic impact studies of legal aid systems indicate that the work of legal aid services reach farther than the clients served. ${ }^{5}$ These studies also emphasize that the benefits of government funded legal aid can have a positive impact on country economies and as a result, can change the trend of restrictive legal aid funding. ${ }^{6}$ In particular, they show what it costs to provide accessible justice, and more importantly, what it will cost if we do not provide accessible justice.

In this paper, author discusses on implications that budget cuts have on generous legal aid systems and its ability to support equal access to justice for those citizens who are unable to afford legal services. ${ }^{8}$ To prove the importance of legal aid funding author note the significance of financial value created by legal aid system through delivery of services to the community as a basis for legal aid funding. Special attention is given to the situation in Croatia.

Cappelletti, M.; Garth, B., Access to Justice and the Welfare State: An introduction, u: Cappelletti, M. (ur.), Access to Justice and the Welfare State, Publications of the European University Institute, Alphen aan den Rijn, Sijthoff, 1981., p. 1.

2 Ibid.

3 Hudson, A., Regeneration, Welfare State and Legal Aid, 1998., p. 1, http://www.alastairhudson.com/legalsystem/legalaid\&welfarestate.pdf. (24 November 2017).

4 Ibid.

5 Farrow, T. C. W, What is access to justice?, Osgoode Hall Law Journal, Vol. 51, No. 3, p. 980.

6 Ibid.

7 Ibid.

8 Goriely, T., Making the Welfare State Work:Changing Conception of Legal Remedies Whithin the British Welfare State, in: The Transformation of Legal Aid: Comparative and Historical Studies, Regan, F.; Paterson, A.; Goriely, T.; Fleming, D. (eds.), Oxford University Press, 2002, p. 90. 


\section{A COMPARATIVE OVERVIEW OF BUDGET CUTS IN GENEROUS LEGAL AID SYSTEMS}

Global economic crisis of 2007-2008 limited public resources more than ever and legal aid services have not been exempt. ${ }^{9}$ Governments have made clear that its first priority is to reduce the burden of debt by reducing public spending. ${ }^{10}$ That had added more negative impact on legal aid funding and many citizens have been left without essential legal advice and support. ${ }^{11}$ The opportunity to secure equal rights become a luxury only available to those with a significant amount of money and the ability to navigate an often complex and frightening legal system alone. ${ }^{12}$

The trend of restrictive legal aid funding was kept a decade after the global economic crisis. ${ }^{13}$ That had negative impact on legal aid budgets in European states with strong tradition of generous legal aid systems regarding funding (e.g. Norway, Northern Ireland, Scotland, England and Wales and Netherlands) whose state budget allocated to legal aid as part of the GDP per capita is several times above the European median of $0,02 \% .{ }^{14}$ Although they commit large legal aid budgets in 2014 they allocated $12 \%$ less money from state budget compared to $2012 .{ }^{15}$ Drop in allocation of state budget per inhabitant to the legal aid systems is especially noticed in Norway, Netherlands, England and Wales, Northern Ireland and Scotland.${ }^{16}$ Among mentioned generous systems, Norway allocated the highest amount of public money for legal aid services

9 Flyinn, A.; Hodgson, J., Access to Justice and Legal Aid Cuts: A Mismatch of Concepts in the Contemporary Australian and British Legal Landscape, u: Flyinn, A.; Hodgson, J., (ur.), Access to Justice and Legal Aid: Comparative Perspectives on Unmet Legal Need, Hart Publishing, Oxford, Portland and Oregon, 2016, p. 1.

10 Logan, R., Legal aid cuts are a major human rights issue, 2016, https://www.opendemocracy.net/openjustice/rachel-logan/amnesty-concludes-that-legal-aid-cuts-are-major-humanrights-issue (24 November 2017).

11 Ibid.

12 Ibid.

13 Countries with best legal aid policies that have significantly reduced their legal aid budgets between 2012 and 2014 are: Norway (- 34,54 \%), UK-Scotland (- 26,18 \%), UK-England and Wales (-16,27 \%) and Netherlands (- 13,18 \%). See: European judicial systems Edition 2016 (data 2014): Efficiency and quality of justice European Commission for the Efficiency of Justice (CEPEJ), Strasbourg, 2016, p. 77.; hereinafter: CEPEJ 2016.

14 Ibid.

15 Cf. CEPEJ 2016, p. 72. and European judicial systems Edition 2014 (data 2012): Efficiency and quality of justice European Commission for the Efficiency of Justice (CEPEJ), Strasbourg, 2014, p. 75.; hereinafter: CEPEJ 2014.

16 Ibid. 
$(53,55 €)$ in 2012 , compared to 2014 , when it allocated $39,90 €$ per inhabitant. ${ }^{17}$ Similar pattern was followed by England and Wales, Northern Ireland, Scotland and Netherlands where public spending went down from high 50,59 $€$ in Northern Ireland to a low $26,90 €$ in Netherlands. ${ }^{18}$

The budget cuts are followed by devolution of legal aid schemes while legal problems and the demand for legal aid services are increasing more quickly than anticipated. That could have negative impact on protection of subjective rights of citizens by simultaneously increasing the extent of unmet legal needs even in most generous legal aid systems. In order to assess the negative impact of budget reduction on generous legal aid systems, it is necessary to analyze the criteria for approving legal services and link them with the reduced value of the budget intended for legal aid. In the following subsections, means and merit criteria will be analyzed on the basis of which legal aid is approved. The average incomes of citizens, together with budget allocations for legal aid, will be determined by the circle of citizens whose legal aid is actually available and numbered through the total number of approved cases.

\subsection{NORWAY}

In Norway legal aid can be granted either in a form of legal assistance outside of court (legal advice), or legal representation in court proceedings (legal representation). ${ }^{19}$ In cases of major significance to the legal aid beneficiary such as appeals against applications for asylum and some types of compensation cases, legal advice can be granted regardless of the beneficiaries' income and assets. ${ }^{20}$ In cases concerning divorce settlement and children, personal injury, unfair or unlawful dismissal or eviction, compensation for victims of violent crimes and appeals against decisions pursuant to the National Insurance Act, legal advice can be granted only if beneficiaries' income and assets are below the prescribed thresholds. ${ }^{21}$ Legal representation can be also granted with and without means test. Thus in child-welfare cases, cases relating to compensation for victims of violent crimes against the perpetrator and cases regarding

\footnotetext{
17 Ibid.

18 Ibid.

19 § 2 Free Legal Aid Act (LOV-1980-06-13-35, Lov om fri rettshjelp Rettshjelpsloven) from 13 June 1980 (in version from 1 July 2017, NL 2017-0099; hereinafter: NoRhjL).

$20 \quad$ See $\S 11$ para. 1 . and $\S 16$. para. 2. NoRhjL.

${ }^{21}$ In exceptional circumstances legal advice can also be granted in other types of cases if they are of particular importance to beneficiary and similar to the prioritized case types. See $\S$ 11 para. 2. and § 16. para. 2. NoRhjL.
} 
forced marriage, legal representation can be granted regardless of income and assets of beneficiary. ${ }^{22}$ In family cases such as divorce settlement and parental custody, personal injury cases, unfair or unlawful dismissal or eviction, legal representation can be granted if beneficiaries' income and assets fall below the thresholds. ${ }^{23}$

For a single person the income threshold must be below $32.278 €(246.000$ NOK) and the assets threshold must be below $13.121 €(100.000 \mathrm{NOK}) .{ }^{24}$ For a married couples and other cohabitants with a joint economy threshold is calculated on basis of their joint gross income which must be below 48.417 $€(369.000 \mathrm{NOK})$ and the net assets which must be below $13.121 €(100.000$ NOK). ${ }^{25}$ As average gross disposable income of households per capita in 2012 was $26.056 €$ and it was increasing through years, as it was $27.627 €$ in 2014 and $28.379 €$ in 2016, legal aid in Norway is available to extended scope of beneficiaries and not only aimed at people on benefits or on very low incomes. ${ }^{26}$ It is estimated that 70 persons per 10.000 inhabitants receives legal aid, which gives Norway an attribute of the most generous provider of legal aid assistance per inhabitant. ${ }^{27}$

Approved state budget allocated to legal aid in 2012 was $6.260 .400,81 €$ (45.883.727 NOK) while in 2014 it was decreased to 5.765.375,93€ $€(52.388 .142$ NOK) and in 2016 again decreased to $4.917 .321,89 €(44.682 .144 \mathrm{NOK}){ }^{28}$ In 2012 the total number of primary legal aid cases was $25.796 .^{29}$ The total number of primary legal aid cases was slightly decreased to 25.056 cases in 2014 and to 25.673 cases in $2016 .^{30}$

\footnotetext{
22 See $\S 16$. and $\S 17$. NoRhjL.

23 Who can receive free legal aid, http://www.sivilrett.no/who-can-receive-free-legalaid.307233.no.html (24 November 2017).

24 Ibid.

25 Ibid.

26 Adjusted gross disposable income of households per capita in PPS, http://ec.europa.eu/ eurostat $/$ tgm/table.do?tab=table \&plugin=0\&language=en\&pcode=tec00113 $\quad(10$ November 2017).

27 Johnsen, J. T., Might Norway learn from Finnish legal aid? A comparison of legal aid in Norway and Finland - summary report, ILAG Conference "Delivering Effective Legal Aid Services Across Diverse Communities", Wellington, 2009, p. 20.

28 Fylkesmannen utbetalte nesten 45 millioner til fri rettshjelp $i$ 2016, https://www.fylkesmannen.no/Oslo-og-Akershus/Folk-og-samfunn/Fri-rettshjelp/Fylkesmannen-utbetalte-nesten-45-millioner-til-fri-rettshjelp-i-2016/ (15 November 2017).

29 Statistikk, https://www.rettsrad.no/ (10 November 2017).

30 Ibid.
} 


\subsection{NETHERLANDS}

In Netherlands legal aid is granted for all kind of legal problems and encompasses: preliminary provision of legal help, primary and secondary legal aid. ${ }^{31}$ The preliminary provision or Roadmap to Justice (Rechtwijzer) offers digital help through the online application, which helps citizens to find solutions for their legal problems in an interactive manner. ${ }^{32}$ Primary help is commonly known as the 'front office' or the Legal Services Counters and provide aid to beneficiaries by clarifying legal matters providing information's and advice in the various fields of law. ${ }^{33}$ The majority of beneficiaries inquiries concern employment (20\%), family law issues (20\%), and contract/consumer law issues $(16 \%) .{ }^{34}$ The eligibility for secondary legal aid is based on the beneficiary annual income and his assets. ${ }^{35}$ Assessment of the legal aid beneficiaries income and assets level, and hence his eligibility for legal aid, is based on his situation two years prior to the application date, the so-called reference year. ${ }^{36}$ The reason to use that year's data is that those data have generally been found correct and therefore final. ${ }^{37}$ So, for a legal aid to be granted in 2014, the beneficiaries income in 2012 is decisive. ${ }^{38}$ In order to qualify for legal aid in 2014, the beneficiaries income in 2012 should not be higher than $25.600 €$ (single person) or $36.100 €$ (married persons / single person with children). ${ }^{39}$ The beneficiaries assets must not exceed $21.139 € .^{40}$ For a certificate to be granted in 2016, beneficiaries income in 2014 is decisive. ${ }^{41}$ In order to qualify for legal aid in 2016, the beneficiaries income in 2014 should not be higher than $26.000 €$ (single person) or $36.800 €$ (married persons / single person with children). ${ }^{42}$ The

31 Legal Aid in the Netherlands a broad outline - 2015, Raad voor Rechtsbijstand/Legal Aid Board, http://www.rvr.org/binaries/content/assets/rvrorg/informatie-over-de-raad/legalaid-brochure_online--2015.pdf (10 November 2017), p. 6.

32 Ibid.

33 Ibid., pp. 6, 14.

34 Ibid., p. 14.

35 Peters, S., National report the Netherlands, Legal Aid in the Netherlands a broad outline, Legal Aid Bord 2016/2017, http://internationallegalaidgroup.org/images/miscdocs/ ILAG_2017_National_Report_-_The_Netherlands_-_Susanne_Peters.pdf $\quad(18$ November 2017), p. 8.

36 Ibid.

37 Ibid.

38 Ibid.

39 Ibid.

40 Legal Aid in the Netherlands a broad outline - 2015, op. cit. (fn. 31), p.16.

41 Peters, National report the Netherlands, Legal Aid in the Netherlands a broad outline, loc. cit.

42 Ibid., p. 9. 
beneficiaries assets must not exceed $21.139 €$. $^{43}$ As average gross disposable income of households per capita in 2012 was $22.947 €$ and it was increasing through years, as it was $23.091 €$ in 2014 and $23.609 €$ in 2016, legal aid in Netherlands is available to extended scope of beneficiaries and it is not only aimed at people on benefits or on very low incomes. ${ }^{44}$

In 2012 , the state provided $486.000 .000 €$ for legal aid and in the period from 2013 to 2014 legal aid budget was decreased to $432.000 .000 €$ and remain the same height in $2016 .{ }^{45}$ From 2012 the number of legal aid cases is in a decline. In $2012,858.914$ cases were granted for primary and 430.614 for secondary legal aid. ${ }^{46}$ In 2014 the total number of legal aid cases granted for primary legal aid was slightly increased to 873.000 and for secondary legal aid to 444.500.47 The number of granted cases in 2016, compared to 2012 and 2014, was again in decline as 734.000 cases were granted for primary and 419.500 cases for secondary legal aid. ${ }^{48}$

\subsection{UNITED KINGDOM}

\section{A. England and Wales}

The Legal Aid, Sentencing and Punishment of Offenders Act 2012 made significant changes to civil legal aid in England and Wales. ${ }^{49}$ The Act not only amended some of the financial eligibility criteria, but also took many areas of civil and family law out of the scope of legal aid. ${ }^{50}$ Previous to LASPO any type of case in England and Wales would be within scope for legal aid, unless it was part of a relatively short list of exclusions. ${ }^{51}$ Now types of cases in scope include: inquests, welfare benefit appeals to upper tribunals, certain immigra-

\footnotetext{
43 Ibid.

44 Adjusted gross disposable income of households per capita in PPS, loc. cit.

45 Legal Aid in the Netherlands a broad outline - 2017, Raad voor Rechtsbijstand/ Legal Aid Board, https://www.rvr.org/binaries/content/assets/rvrorg/informatie-over-de-raad/12835_legalaid-brochure_2017.pdf (10 November 2017), p. 6.

46 Legal Aid in the Netherlands a broad outline - 2013, Raad voor Rechtsbijstand/Legal Aid Board http://www.rvr.org/binaries/content/assets/rvrorg/informatie-over-de-raad/brochure-legalaid_juni2013_webversie.pdf (10 November 2017), pp. 13, 23.

47 Legal Aid in the Netherlands a broad outline - 2015, op. cit. (fn. 40), pp. 13, 22.

48 Legal Aid in the Netherlands a broad outline - 2017, op. cit. (fn. 45), str. 14, 23.

49 Legal Aid, Sentencing and Punishment of Offenders Act 2012, c.10 from 1 May 2012 (in version from 25 November 2017, SI 2012/2906; hereinafter: LAPSO).

50 Sallberg, Y.; Pollitowski, B., Civil Legal Aid: England \& Wales, Scotland and N Ireland compared, Briefing paper, no. 7603, House of Commons, 2016, p. 5.

51 Ibid.
} 
tion cases, family law in cases of domestic violence or some cases involving children, mental health. ${ }^{52}$ Legal aid can be split by area of law into the categories of legal help, controlled legal representation and civil representation. ${ }^{53}$ Legal help includes advice and assistance about a legal problem, but does not include representation or advocacy in proceedings. ${ }^{54}$ Controlled legal representation involves representation specifically at mental health and immigration tribunals. ${ }^{55}$ Civil representation is representation by solicitors and barristers for civil cases, which could go to court. ${ }^{56}$

To be eligible for legal aid the beneficiary must meet certain financial eligibility criteria, taking into account gross and disposable income and whether they are in receipt of certain state benefits. ${ }^{57}$ Where civil legal aid is means tested, the means test looks at both the beneficiaries income and capital. ${ }^{58}$ Beneficiary will be eligible for civil legal aid where their monthly disposable income does not exceed 858,4 $€(733 £)$ and their disposable capital does not exceed $9.369,00 €(8.000 £) .{ }^{59}$ The exceptions are where the beneficiary is seeking legal representation in respect of certain immigration matters before the First-tier Tribunal or the Upper Tribunal. ${ }^{60}$ In those cases, beneficiary will be eligible for civil legal aid where their disposable monthly income does not exceed 858,4 $€(733 £)$ and their disposable capital does not exceed 3.513,3 $€(3,000 £) .{ }^{61}$ An average gross disposable income of households per capita in England was $20.694 €(17,066 £)$ in $2012,22.184 €(18.315 £)$ in 2014 and $19.584,99 €(19.106 £)$ in 2015 and similarly in Wales was $17.066 €(14.623$ $£)$ in $2012,18.535,15 €(15.302 £)$ in 2014 and $20.914,81 €(16.341 £)$ in 2015 , which indicate that legal aid is aimed at people on benefits or on very low

\footnotetext{
52 Since LAPSO was enacted legal aid cases are within scope only if they are of a type set out in Part 1 of Schedule 1 to the LAPSO and subject to the exclusions in Part 2 of that Schedule.

53 User Guide to Legal Aid Statistics, England and Wales, Ministry of Justice statistics, 2017, https://www.gov.uk/government/uploads/system/uploads/attachment_data/file/623329/userguide-to-legal-aid-statistics-in-england-and-wales-jan-mar-17.pdf (7 November 2017), p. 4.

54 Ibid.

55 Ibid.

56 Sallberg; Pollitowski, op. cit. (fn. 50), p. 12

57 Annex C: The Current Legal Aid Financial Eligibility Rules - Summary, https://consult.justice.gov.uk/digital-communications/legal-aid-eligibility-and-universal-credit/supporting_documents/annexcsummaryofcurrentlegalaidfinancialeligibilityrules.pdf (22 November 2017), p. 1.

58 Ibid.

59 Ibid., p. 2.

60 Ibid.

${ }^{61}$ Annex C: The Current Legal Aid Financial Eligibility Rules - Summary, loc. cit.
} 
incomes. ${ }^{62}$ Along with the financial criteria, civil cases must also be within the scope of the civil scheme and have sufficient prospect of success (merit) in order to be funded. ${ }^{63}$ Where prospects are classified as marginal or borderline (more than a $45 \%$ but less or equal 50\%) the prospect test will still be met if the case is of significant wider public interest; with overwhelming importance to the individual; or, in certain proceedings, the substance of the case relates to a breach of rights granted by The European Convention on Human Rights. ${ }^{64}$ Also it is possible to receive civil legal aid even if the circumstances of the case or beneficiaries fall out with the normal criteria of the scheme ${ }^{65}$ However, funding outside the legal aid scheme's normal criteria is only available in very limited circumstances. ${ }^{66}$

The implementation of LASPO has resulted in a large reduction of legal aid expenditures and workload. ${ }^{67}$ Total civil legal aid expenditure was 1.175.328.453,13 $€(941.000 .000 £)$ in period from 2012 to $2013,758.820 .458,12 €(592.886 .000$ $£)$ in period from 2014 to 2015 and $689.847 .033,75 €(613.723 .000 £)$ in period from 2015 to $2016 .{ }^{68}$ In period from 2012 to 2013 legal help was granted in 573.632 cases and in period from 2013 to 2014 it was granted in 172.846 cases, which represent a drop of 70 per cent. ${ }^{69}$ In 2014 civil representation was given in 497,000 cases, with a drop of 46 per cent since $2012 .{ }^{70}$ Drop of caseload in 2016 shows further reduction in legal help and civil representation, which are levelled out at around one-third and two-third of 2012 levels. $^{71}$

62 Regional gross disposable household income (GDHI): 1997 to 2014, https://www.ons.gov. uk/economy/regionalaccounts/grossdisposablehouseholdincome/bulletins/regionalgrossdisposablehouseholdincomegdhi/2014 (22 November 2017).

63 Annex C: The Current Legal Aid Financial Eligibility Rules - Summary, loc. cit.

64 The Civil Legal Aid (Merits Criteria) (Amendment) Regulations 2016, SI 2016/781.

65 Sallberg; Pollitowski, op. cit. (fn. 50), p. 9.

66 Ibid.

67 Ibid., p.12.

68 Legal Aid Agency Annual Report and Accounts 2012 to 2013, https://www.gov.uk/government/publications/legal-services-commission-annual-report-and-accounts-2012-to-2013 (7 November 2017), p. 15.; Legal Aid Agency Annual Report and Accounts 2015 to 2016, https://www.gov.uk/government/publications/legal-aid-agency-annual-report-and-accounts2015-to-2016 (7 November 2017), p. 65, Legal Aid Agency Annual Report and Accounts 2016 to 2017, https://www.gov.uk/government/publications/legal-aid-agency-annual-report-and-accounts-2016-to-2017 (7 November 2017), p. 74.

69 Legal Aid Statistics in England and Wales, 2013-2014, https://www.gov.uk/government/ statistics/legal-aid-statistics-april-2013-to-march-2014 (8 November 2017), p. 63.

70 Ibid.

71 Legal Aid Statistics in England and Wales: October to December 2016, https://www.gov.uk/ government/statistics/legal-aid-statistics-october-to-december-2016 (7 November 2017), p. 21. 


\section{B. Scotland}

In Scotland legal aid is obtainable as primary legal aid (Advice and Assistance) and secondary legal aid (Civil Legal Aid).$^{72}$ Legal aid is available for a broad range of categories of case as virtually all types of civil disputes have a form of legal aid provision..$^{73}$ Advice and assistance is a type of legal aid that allows for advice to be given on any matter of Scots law. ${ }^{74}$ It does not, however, generally cover steps in connection with instituting, conducting, or defending proceedings. ${ }^{75}$ Advice and assistance is granted only if two statutory tests are met: the issue must be a matter of Scots law and the applicant must be financially eligible (means test) ${ }^{76}$ Since advice and assistance does not include assistance in advocacy in court proceedings, in certain cases it is possible to extend this form of assistance to representation (Assistance by Way of Representation and Legal Aid; hereinafter: ABWOR). ${ }^{77}$ ABWOR is a type of advice and assistance that allows for a solicitor to take steps in connection with instituting, conducting, or defending certain defined types of proceedings. ${ }^{78}$ Advice and assistance and ABWOR means test is based on the beneficiaries income and capital for the seven days prior to the date of the application. ${ }^{79}$ The weekly disposable income limits are $119,4 €(102 £)$ (lower) and $278 €(238$ $£)$ (upper) and the disposable capital limit is $1.363,19 €(1.664 £) .{ }^{80}$ As part of the granting process, a financial contribution is also calculated due to be paid by the beneficiaries. Currently, a contribution is payable by those with weekly

72 The key legal aid legislation in Scotland is the Legal Aid (Scotland) Act 1986, c. 47 from 25 July 1986 (in version from 25 November 2017, SI 1986/1358; hereinafter: LAA)

73 In Scotland, civil legal aid is available for all cases before the courts listed in Part 1 of Schedule 2 of the LAA. This does not include representation at most tribunals. Part 2 of Schedule 2 in the LAA lists cases where civil legal aid is not available which includes small claims cases in the Sheriff Courts, simplified divorce applications or proceedings wholly or partly concerned with defamation. However, legal aid for "Advice and Assistance" or "Assistance By Way Of Representation" may be available in these instances. See A Sustainable Future for Legal Aid, The Scottish Government, Edinburgh, 2011, http://www.gov.scot/Resource/ Doc/359686/0121521.pdf (7 November 2017), p. 3.

74 Legal Assistance in Scotland fit for the 21st century, Law Society of Scotland, Discussion Paper, https://www.lawscot.org.uk/media/409526/legal-assistance-in-scotland-discussion-paper.pdf (7 November 2017), p. 7.

75 Ibid.

76 Part II Section 8 LAA.

77 What does legal aid cover?, https://scotland.shelter.org.uk/get_advice/advice_topics/complaints_and_court_action/legal_costs/what_does_legal_aid_cover (7 November 2017).

78 Legal Assistance in Scotland fit for the 21st century, op. cit. (fn. 74), pp. 8.-9.

79 Ibid.

80 Ibid. 
disposable income over $114 €(102 £) .{ }^{81}$ Disposable income is assessed by taking into account income from all sources received by the beneficiaries or their partners in the seven days up to the date of the application. Contributions are payable in bands that rise with disposable income, starting at 7,8€ $(7 £) .{ }^{82}$

Civil legal aid as type of legal aid enables the solicitor to pursue or defend a case in court if three statutory tests are met: there must be a legal basis to the case (probable cause); it must be reasonable in the particular circumstances of the case that the beneficiary should receive legal aid; and the beneficiary must be financially eligible. ${ }^{83}$ Beneficiaries are eligible for civil legal aid if disposable income doesn't exceed $29.805,31 €(25.450 £)$ a year, if disposable capital doesn't exceeds $14.786,71 €(12.626 £)$ and if it appears that he can't afford to proceed without legal aid. ${ }^{84}$ As an average gross disposable income of households per capita in Scotland was $19.726 €(16.267 £)$ in 2012, 20.707,04 € $(17.095 £)$ in 2014 and $23.441,33 €(18.315 £)$ in 2015 , legal aid isn't, like in England and Wales, aimed at people on benefits or on very low incomes. ${ }^{85}$ Scope of beneficiaries can be further extended as cases which are not within the criteria for civil legal aid could also be funded under civil legal aid scheme. ${ }^{86}$ These cases include: legal aid for children's hearings; advice and assistance schemes which provide help for people to pay for written or oral advice from a solicitor on any matter of Scots law; ABWOR which allows for legal aid funding to pay for a solicitor to appear in a court or tribunal not covered by the other legal aid schemes in particular circumstances. ${ }^{87}$

Although the system of legal aid is available to a wide range of users, reducing budget allocations from $59,427,876.44 €(49,007,000 £)$ in the period from 2012 to 2013 to $54,468,349.60 €(40,850,000 £)$ in the period from 2016 to 2017, resulted in a reduction in the number of cases in which legal aid was approved. ${ }^{88}$ The total net cost of advice and assistance, ABWOR, civil legal aid fell from $59.427 .876,44 €(49.007 .000 £)$ in the period from 2012 to 2013 to

\footnotetext{
81 Ibid.

82 Ibid.

83 Ibid., pp.12-13

84 Part II Section 15 LAA

85 Regional gross disposable household income (GDHI): 1997 to 2014, op. cit. (fn. 62), p. 9.

86 Sallberg; Pollitowski, op. cit. (fn. 50), p. 9.

87 Ibid.

88 Scottish Legal Aid Board Annual Report 2016-2017, http://www.slab.org.uk/export/sites/ default/common/documents/Annual_report_2016_17/SLAB_Annual_Report_2016-17_Appendix_1_-_Key_Statistics_2016-17.pdf (7 November 2017), p. 6.; Sallberg; Pollitowski, op. cit. (fn. 50), p. 16.
} 
$54.468 .349,60 €(40.850 .00 £)$ in the period of 2016 to $2017 .{ }^{89}$ There has been a general decline in the civil legal assistance caseload in Scotland over the past five years. ${ }^{90}$ Total civil advice and assistance cases workload in period from 2012 to 2013 was 80.473 and in period from 2014 to 2015 declined to $63.880 .^{91}$ Negative trend continued in period from 2016 to 2017 when civil legal assistance was granted in 61.780 cases. $^{92}$ This is largely due to a reduction in the demand for advice and assistance. ${ }^{93}$ Likewise the number of applications for civil representation through the civil legal aid scheme has fallen. ${ }^{94}$ In period from 2012 to 2013 civil legal aid was granted in 13.427 cases and in period from 2014 to 2015 in 12.977 cases. ${ }^{95}$ The decreasing trend in providing civil legal aid continued till period of 2016-2017 when it slightly increased to 13.425 cases. ${ }^{96}$ However, there has been an increase in ABWOR due to an increase in the number of immigration, asylum and mental health cases, which fall out with the scope for civil legal aid at tribunal level. ${ }^{97}$ In period from 2012 to 2013 ABWOR was granted in 4.721 cases and from that period it started increasing to 5.101 cases in period from 2013 to 2014 and to 5.405 cases in period from 2014 to $2015 .^{98}$

\section{Northern Ireland}

Legal aid services in Northern Ireland cover two types of legal aid: primary legal aid (Legal advice and Assistance) and secondary legal aid (Legal Aid). ${ }^{99}$ Legal advice and assistance is a type of legal aid that covers help in a form of a

\footnotetext{
89 Scottish Legal Aid Board Annual Report 2016-2017, p. 3.

90 Civil Legal Aid: England \& Wales, Scotland and N Ireland compared, P.16.

91 Scottish Legal Aid Board Annual Report 2016-2017, op. cit. (fn. 50), p. 3.

92 Ibid.

93 Sallberg; Pollitowski, op. cit. (fn. 50), p. 12.

94 Ibid., p. 16.

95 Scottish Legal Aid Board Annual Report 2016-2017, loc.cit.

96 Ibid.

97 Sallberg; Pollitowski, op. cit. (fn. 50), p. 13.

98 Scottish Legal Aid Board Annual Report 2014-2015, http://www.slab.org.uk/export/sites/ default/common/documents/Annual_report_2014_2015/SLAB_Annual_Report_2014-15_-_ Appendix_3_-_Civil_legal_assistance.pdf (7 November 2017), p. 2.; Scottish Legal Aid Board Annual Report 2013-2014, http://www.slab.org.uk/common/documents/Annual_Report_2013_2014/SLAB_Annual_Report_2013-2014_-_Appendix_3_-_Civil_legal_assistance.pdf (7 November 2017), p. 2.
}

99 The legal aid impact test - assessing the implications of government proposals on courts and legal aid, http://www.courtsni.gov.uk/en-GB/S<afts5gwfervices/LegalAid/LAImpactTest/ (25 November 2017). 
general advice on any legal problem, preparing applications for civil legal aid certificates, writing letters, drafting documents, negotiation, taking statements, getting an opinion from a Barrister, etc. ${ }^{100}$ Advice and assistance covers a wide range of matters, so long as they are matters of Northern Ireland law and beneficiary qualify financially. ${ }^{101}$ Qualification for legal advice and assistance is subject to the beneficiaries financial circumstances (means test). ${ }^{102}$ Thus legal advice and assistance is available if a beneficiaries disposable income does not exceed $274 €(234 £)$ per week and his disposable capital doesn't exceed $1.171,1 €(1.000 £) .{ }^{103}$ In limited set of cases beneficiary could apply for legal advice and assistance that also covers representation before court (Assistance by Way of Representation, hereinafter: ABWOR). ${ }^{104}$ ABWOR permits legal representation in certain proceedings in Magistrates courts or Mental Health Review Tribunal. ${ }^{105}$ Legal aid as type of legal service includes representation in court proceedings. ${ }^{106}$ Legal aid is available for cases in the Supreme Court, Court of Appeal, High Court, Divisional Court, Lands Tribunal and Enforcement of Judgments Office. ${ }^{107}$ It is not available for proceedings in the Coroners court and most other tribunals or cases involving defamation. ${ }^{108}$ In order qualify for civil legal aid beneficiaries have to demonstrate that they have reasonable grounds for taking, defending or being party to proceedings (merits test). ${ }^{109}$ Beside merit test, financial eligibility (means test) must be satisfied. ${ }^{110}$ In such manner legal aid is available for beneficiary whose disposable income doesn't exceed $11.637 .54 €(9.937 £)$, his disposable capital doesn't excess $7.905 €(6.750 £)$ and it appears that he can't afford to proceed without legal aid. ${ }^{111}$ If beneficiaries disposable income exceeds $3.929 €(3.355 £)$ or if his

\footnotetext{
100 Dickson, B., The Legal System of Northern Ireland, SLS Legal Publications, 2005, p. 147.

101 Legal aid, https://www.nidirect.gov.uk/articles/legal-aid (10 November 2017).

102 The legal aid impact test - assessing the implications of government proposals on courts and legal aid, loc. cit.

103 Part II Section 3 Legal Aid, Advice and Assistance (Northern Ireland) Order 1981 from 18. February 1981 (in version from 25. November 2017, SI 1981/228 (NI 8); hereinafter: LAAA'NI)

104 Dickson, loc. cit. .

105 Ibid.

106 Ibid, p. 150.

107 Sallberg; Pollitowski, op. cit. (fn. 50), p. 5.

108 Ibid

109 Dickson, op. cit. (fn. 100), p. 151.

110 The legal aid impact test - assessing the implications of government proposals on courts and legal aid, loc. cit.

111 Part II Section 10 Paragraph 4. LAAA’NI.
} 
disposable capital exceeds $3.513 €(3.000 £)$ he is obliged to pay contributions for legal aid. ${ }^{112}$ As average gross disposable income of households per capita in Northern Ireland was $19.726,02 €(16.791 £)$ in $2012,21.760,87 €(17,965$ $£)$ in 2014 and $20.367,01 €(15.913 £)$ in 2015 , legal aid is aimed at people on benefits or on very low incomes. ${ }^{113}$ Yet there are specific circumstances under which the scope of beneficiaries could be extended as some applications outside civil legal aid can obtain funding for representation through the Statutory Exceptional Grant Scheme which allows that legal aid funding may be provided where the case would otherwise be excluded from the legal aid scheme. ${ }^{114}$

Although the system of legal aid is available to a narrow circle of users, the system favors the stability of budget allocations. Thus, legal aid expenditure in Northern Ireland rose drastically from 2000 to 2010 but has since stabilized. ${ }^{115}$ From 2009 to 2010 expenditure increased from 18.738.117,81 $€$ to 43.331.897,44 € (form 16.000.000 £ to 37.000.000 £). ${ }^{116}$ With small level of variation in financing between years, since 2011 total expenditure on legal aid has remained at around 117.113.236,34 € (100.000.000 £) per year. ${ }^{117}$ Legal advice and assistance was in from 2012 to 2013 granted in 34.854 cases. ${ }^{118}$ In same period ABWOR was granted in 3.069 cases while legal aid was granted in about 5.885 cases. ${ }^{119}$ In period from 2014 to 2015 legal advice and assistance was granted in 42.001 cases, ABWOR was granted in 3.248 cases while legal aid was granted in about 5.885 cases. ${ }^{120}$

\section{FINANCIAL CHALLENGES OF CROATIAN LEGAL AID SYSTEM}

In 2013 Croatia adopted new Legal Aid Act which ruled out Legal Aid Act from 2008 that has been severely criticized as inadequate and non-functional

\footnotetext{
112 Part II Section 12 Paragraph 1. LAAA'NI.

113 Regional gross disposable household income (GDHI): 1997 to 2014, op. cit. (fn. 62).

114 Sallberg; Pollitowski, op. cit. (fn. 50), p. 10.

115 Managing legal aid, Northern Ireland Audit Office, 2016, http://www.niassembly.gov.uk/ globalassets/committee-blocks/pac/niao-reports/managing-legal-aid-report.pdf (23 November 2017), p. 9.

116 Ibid.

117 Ibid.

118 Ibid., p. 17.

119 Ibid.

120 Ibid.
} 
from the point of view of target groups for whom it was intended. ${ }^{121}$ Although, CLAA/13 provides legal aid to a wide range of beneficiaries without insisting on strict verification of property census, the fight for improvement of the scheme continues as funding is insufficient. ${ }^{122}$ To analyze whether Croatia follow the rule that restrictive legal aid budget have negative impact on the number of granted cases, it is necessary to analyze legal aid scope, financial data regarding legal aid budget and number of granted legal aid cases.

\subsection{THE SCOPE OF LEGAL AID}

Legal aid in Croatia is available in form of primary and secondary legal aid. Primary legal aid includes general legal information, legal advice, the preparation of submissions to government agencies, representation in proceedings before the government agencies, and legal assistance in the peaceful resolution of the dispute out of court. ${ }^{123}$ As primary legal aid has a preventative function by decreasing the number of unnecessary legal proceedings and relieves the burden from courts and administrative bodies, it is encouraged for a very broad circle of legal problems, irrespective or their nature. ${ }^{124}$ Therefore, under CLAA/13 limitations of topics for primary legal aid are permissible only if: the beneficiaries have sufficient knowledge and ability to protect their rights; the legal aid is granted under the provision of special regulations; the legal aid application is manifestly ill-founded and the material circumstances of the beneficiaries do not require legal aid because it does not jeopardize his maintenance or maintenance of members of his household. ${ }^{125}$

Secondary legal aid includes legal advice, compilation of submissions in the proceedings of the protection of workers' rights in front of their employer, filing of complaints in court proceedings, representation in court proceedings

\footnotetext{
121 See Johnsen, J. T.; Stawa, G.; Uzelac, A., Evaluation of the Croatian Legal Aid Act and its implementation (International Expertise), Zagreb, Oslo, Beč, 2010.; Uzelac, A.; Preložnjak, B., The Development of Legal Aid Systems in Western Balkans. A Study of Controversial Reforms in Croatia and Serbia, Kritisk Juss, Vol. 38, No. 3-4, 2012., pp. 261-287.; Preložnjak, B., Besplatno informiranje i savjetovanje kao pretpostavka pristupa pravosuđu. Evaluacija uređenja u Hrvatskoj iz komparativne perspective, Zbornik Pravnog fakulteta u Zagrebu, Vol. 66, No. 6, 2016, pp. 721-742.

122 See Legal Aid Act (Zakon o besplatnoj pravnoj pomoći, Narodne novine, No. 143/2013); hereinafter: CLAA/13

123 Art. 9 CLAA/13

124 Art. 10 CLAA/13.

125 Ibid
} 
and legal aid in a peaceful resolution of the dispute. ${ }^{126}$ Approval of secondary legal aid includes exemption from payment of court fees and exemption from payment of litigation costs. ${ }^{127}$ Similarly, to primary legal aid, secondary legal aid could be granted only if: legal aid beneficiary does not have ability to represent himself before court; the case is not conducted for vexatious or capricious reasons; and legal aid is not granted under the provisions of special regulations. ${ }^{128}$ Unlike primary legal aid, secondary legal aid is made dependent on legal problems for which the aid is sought and is granted for legal problem of high welfare importance. Thus, beneficiaries can obtain secondary legal aid subsidized by the State only in procedures that are related to property rights, employment disputes, family law disputes, enforcement proceedings and insurance proceedings, and some forms of the alternative dispute resolution. ${ }^{129}$

Approval of both types of legal aid is dependent on the economic status of the beneficiary and the members of his/her household. Thus, legal aid could be granted only if the beneficiaries material circumstances are such that the payment of professional legal assistance could endanger his maintenance and maintenance of the members of his household. ${ }^{130}$ Additionally, for the approval of secondary legal aid beneficiary must be full financial screened. He and the members of his household have to meet two conditions: the total income must not exceed, per household member, the amount of the budget base and the total value of the property owned must not exceed the amount of 60 budget bases. ${ }^{131}$ Exceptionally, secondary legal aid will be granted if the assumptions regarding income and property value are not fulfilled only if the beneficiary, for objective reasons, can't have access to total revenue and assets and if a part of the total revenue and assets that beneficiary can hold does not exceed the amounts of 60 budget bases. ${ }^{132}$ Secondary legal aid could be also approved without financial screening in cases of: child maintenance proceedings; compensation proceedings regarding criminal offense damages; maintenance proceedings regarding social welfare rights and proceedings under the Law on the Rights of Croatian Homeland War Veterans and their Family Members and the Law

\footnotetext{
126 Art.12 CLAA/13.

127 Art. 12 para. 2 CLAA/13.

128 Art. 13 para 1 CLAA/13

129 Art. 5 para. 3 a-e CLAA/13.; The international evaluation notes that the legal problem criteria are too narrowly shaped to secure everyone proper access to the courts. In practice, the scheme has not been very effective in providing legal aid. See Johnsen; Stawa; Uzelac, op . cit. (fn. 121), p.32.

130 Art. 10; Art. 13 para. 1, 3, 4. CLAA/13.

131 Art. 14, para. 1 CLAA/13.

132 Art. 14, para. 2 CLAA/13.
} 
on Protection of Military and Civilian Invalids of War. ${ }^{133}$ As Croatia's disposable household income is averaging 10.881 € (81.817,00 HRK) from 2010 to 2016, with law record of $10.547 €(79.308,00 \mathrm{HRK})$ in 2013 , legal aid is not exclusively aimed at people on benefits or on very low incomes. ${ }^{134}$

\subsection{FUNDING OF THE LEGAL AID SYSTEM}

The Croatian legal aid system is financed from the state budget, but funds can be also provided from the budgets of local and regional self-government and through contributions. ${ }^{135}$ The financial support to legal aid system should primary come from the state, as the legislator softened the grant criteria and broadened the legal aid user's cycle with an aim to provide equal access to justice for all citizens. Although CLAA/13 grant legal aid without insisting on strict verification of property census, in past several years legal aid became increasingly unavailable due lack of proper funding. The reason for this is that the legal aid funds are not allocated in accordance with the law, so they can't be used according to the real legal aid needs. This creates the wrong picture that legal aid system doesn't need additional funding which results in a continuous reduction of available legal aid budget. The erosion of financing legal aid has been going on for years. Thus, in 2012, from the legal aid budget $168.200 €,(1.261 .500 \mathrm{HRK})$ for the purpose of providing primary legal aid $26.719 €\left(200.397\right.$ HRK), was allocated. ${ }^{136}$ A similar trend continued in 2013, so the government allocated for legal aid $240.000 €(1.800 .000 \mathrm{HRK})$, where for primary legal aid $21.333 €(160.000$ HRK) was spent, while on secondary legal aid it was spent $23.414,15 €\left(176,678.30\right.$ HRK). ${ }^{137}$ Negative trend of allocation of resources for legal aid from the state budget has continued in the coming years. In 2014 and 2015, a temporary increase in the legal aid budget was recorded when $397.084 €(3.030 .000 \mathrm{HRK})$ and $375.477,49 €$ $\left(2,880,000\right.$ HRK) was allocated from the budget. ${ }^{138}$ Out of the above amounts

\footnotetext{
133 Art. 15 para. 1 CLAA/13.

134 Regional gross disposable household income (GDHI): 1997 to 2014, op. cit. (fn. 62).

135 Art. 11 para. 1; art. 16 para. 1 CLAA/13.

136 See Report on Exercising the Right to Legal Assistance and Expenditures in 2012, Zagreb, 2013, p. 21; hereinafter: 2012 Report.

137 Negative trend is the number of items in which the primary legal aid provided has been resumed. Thus, primary legal aid has been granted in only 234 cases, so the largest part of the budget is allocated in 2013 to the financing of secondary legal aid. See the Report on Exercising the Right to Legal Assistance and Expenditures in 2013, Zagreb, 2014, p. 21.; hereinafter: 2013 Report

138 Report on Exercising the Right to Legal Assistance and Expenditures in 2014, Zagreb, 2015, p. 12.; hereinafter: 2014 Report; Report on Exercising the Right to Legal Assistance and Expenditures in 2015, Zagreb, 2016, p. 12.; hereinafter: 2015 Report.
} 
in $2014,190.415 .13 €(1.450,00 \mathrm{HRK})$ was spent on primary legal aid and 158.461.89 $€(1.206 .678 \mathrm{HRK})$ for secondary legal aid. ${ }^{139}$ A similar trend was observed in 2015 when 195.899,85 € (1.500.000 HRK) was spent for primary and $180.222,51 €(1.379 .959 \mathrm{HRK})$ for secondary legal aid. ${ }^{140}$ In 2016 there was a greater decrease in the budget allocation, when 2.848.656, $63 €$ $(694,413.92 \mathrm{HRK})$ was allocated for primary legal aid and for secondary legal aid $281.907 .35 €(2.153 .792,71 \mathrm{HRK}){ }^{141}$

Reduction of state budget was followed by decreasing number of cases in which legal aid was provided. Therefore, in 2012 primary legal aid was granted in 448 cases and secondary legal aid was granted in 4.936 cases. ${ }^{142}$ In 2013 the legal aid grants were still decreasing so primary legal aid was granted in 234 cases and secondary in 5.838 cases. ${ }^{143}$ Increase of legal aid budget had positive impact to legal aid provision so primary legal aid was granted in 647 cases and secondary legal aid was granted in 7.949 cases. ${ }^{144}$ In 2015 secondary legal aid was granted in 11.501 cases and in 2016 in 6.956 cases, while there is no data regarding primary legal aid. ${ }^{145}$

\section{ECONOMIC IMPACTS OF LEGAL AID CUTS ON PUBLIC BUDGETS}

In generous legal aid systems expenditures are in constant fall. Whilst figures regarding legal aid budgets suggest that the governments have made significant budget savings, they ignore any knock-on financial costs that could offset these savings. ${ }^{146}$ Namely, the economic restrictions in legal aid funding can cause real harm to the individuals and communities that rely on legal aid services, as legal aid systems struggle to carry out their mission to provide high quality

\footnotetext{
1392014 Report, p. 12.

1402015 Report, Zagreb, 2016, p. 12.

141 Report on exercising the Right to Legal Assistance and Expenditures in 2016, Zagreb, 2017, p. 13.; hereinafter: 2016 Report.

1422012 Report, p. 12.

1432013 Report, p. 7.

1442014 Report, p. 8.

1452016 Report, p. 9.

146 Cuts that hurt: The impact of legal aid cuts in England on access to justice, Amnesty International UK, London, 2016, https://www.amnesty.org/en/documents/eur45/4936/2016/en/ (25 November 2017), p. 9.

Cookson, G.; Mold. F., The business case for social welfare advice services. An evidence review - lay summary, 2014., http://www.lag.org.uk/media/173260/julyaug_la_lowcommission. pdf (25 November 2017).
} 
protection of subjective rights. If the costs of justice are too high, protection of subjective rights could become unavailable to those with insufficient means. ${ }^{147}$ On the other side, ineffective legal aid systems go far beyond the negative impact on the subjective rights of citizens. ${ }^{148}$ It reaches all citizens in a real and direct economic way. ${ }^{149}$ The economic losses caused by legal aid systems that are neither efficient nor effective do not prevent many problematic outcomes that drain public funds. ${ }^{150}$ Recognition of causal link between an ineffective legal aid system and larger economic costs should be the first step toward an increasing the legal aid budgets. ${ }^{151}$

Several economic impact analysis concluded that early resolution of legal problems can relieve financial pressure on other areas of public spend by preventing much bigger legal issues, before they become more difficult and expensive to resolve. ${ }^{152}$ It means that legal aid not only pays for itself, but also makes a significant contribution to households, local economies and public expenditure by minimizing negative effect of legal problems to citizens lives. ${ }^{153}$ Therefore, timely provided legal aid services can lead to positive outcomes such as benefit gains, debt written off and charity grants. ${ }^{154}$ They could also lead to numerous soft outcomes including reduced stress, reduction in depression and improved sleeping patterns as unsolved legal aid problems can affect quality of life. ${ }^{155}$ Beside above mentioned outcomes, legal aid could contribute to other outcomes such as employment gained, suicide prevented, crime prevented and improvements in family relationships. ${ }^{156}$ If we only consider example of the family being wrongly evicted by an overzealous landlord we can see that with

147 Loghan, R., Legal aid cuts are a major human rights issue, 2016, https://www.opendemocracy.net/openjustice/rachel-logan/amnesty-concludes-that-legal-aid-cuts-are-major-humanrights-issue (27 November 2017).

148 Magnuson, M. J., Frank, M. S., The High Cost of Efficiency: Courthouse Tech and Access to Justice, The Professional Lawyer, Vol. 22, No. 4, 2014, p.2

149 Ibid.

150 Cookson; Mold, loc. cit.; Magnuson, Frank, loc. cit.

151 Magnuson; Frank, loc. cit.

152 Society launches survey on impact of legal aid, https://www.lawscot.org.uk/news/2017/09/ impact-of-legal-aid-survey/ (27 November 2017).

153 Cookson; Mold, loc. cit.

154 Jaynes, B., Proving the value of Advice Services in Devon: An impact study of the services provided by Citizens Advice Bureaux using Social Return on Investment, Citizens Advice Bureau, 2015, p. 12.

155 Ibid.

156 Ibid. 
access to a legal aid, unjust evictions could be prevented. ${ }^{157}$ As a result, homelessness is avoided, expensive emergency shelter costs are unneeded, police costs, emergency room visits and health care costs are reduced. ${ }^{158}$

Economic impact studies are important for governments especially at times of legal aid reforms, as they demonstrate that the savings made to the state raise an important question when it comes to making cuts to legal aid services. Those studies are made on social investment return (hereinafter: SROI) framework which predicts how much social value will be created if the legal aid activities meet their intended outcomes. ${ }^{159}$ SROI results can especially pinpoint the fiscal value of legal aid services, the cost efficiency of these services and the long-term financial value to the community. ${ }^{160}$ The process of an SROI analysis leads to the ratio between the value of the benefits and the value of the investment. ${ }^{161}$

Currently, economic impact studies are, among analyzed legal aid systems, conducted only in the England and Wales and they strongly suggest that the fiscal and economic benefits generated by legal aid services are significant. For example the Citizens Advice Bureau study from 2010 showed that if government would invest $1,12 €(1 £)$ in legal aid, the state will benefit from saving its budget in amount of : $2,2 €(2.34 £)$ from legal aid spent on housing advice; $3,3 €(2.98 £)$ from legal aid spent on debt advice; $8,89 €(8.80 £)$ from legal aid spent on benefits advice; and 7,78 € (7.13£) from legal aid spent on employment advice. ${ }^{162}$ Similarly, in 2010 New Economics Foundation (NEF) and

157 Abel, L., Vignola. S., Economic and Other Benefits Associated with the Provision of Civil Legal Aid, Seattle Journal for Social Justice, Vol. 9, No. 1, 2010, pp. 148-150.

158 Ibid.

159 There are several main steps to calculating the Social return of investment (hereinafter: SROI): defining the boundaries, identifying the key stakeholders, identifying the inputs and outputs of each activity involved in legal aid scope, developing outcome indicators, and putting a monetary value on those indicators See: How To: Calculate the social return on investment to make better decisions, http://www.mainebiz.biz/article/20160725/CURRENTEDITION/307209991/how-to:-calculate-the-social-return-on-investment-to-make-betterdecisions (25 November 2017).

160 Byrnes, J., What's the True Value of Your Services? Use Social Return on Investment to Find Out.

Prove the worth of your organization's work with this process., http://www.csaco.org/ files/70906026.pdf (27 November 2017), p. 1.

161 Brouwers, J., et. al., Social Return On Investment: A practical guide for the development cooperation sector, Utrecht, 2010., str. 14.

162 Cookson; Mold, op. cit. (fn. 146), p. 2..; Towards a business case for legal aid, Paper to the Legal Services Research Centre's eighth international research conference, Citizens Advice, 2010, https://www.accesstojusticeactiongroup.co.uk/wp-content/uploads/2011/07/towards_a_ business_case_for_legal_aid.pdf (27 November 2017), p. 2. 
Advice UK study estimated the social return on investment for cases of debt advice and housing advice as over $10 €(9 £)$ for every $1,1 €(1 £)$ invested. ${ }^{163}$ In 2014 study of the impact of Citizens Advice services in the Bath and NorthEast Somerset area found that for every $1,2 €(1 £)$ spent on Citizens Advice services there was a benefit to individuals and/or other stakeholders (including the state) of between $39,8(33 £)$ and $60,36(50 £)$ over a period of five years. ${ }^{164}$ Those results strongly suggest that economic benefits of legal aid should be powerful motivators for governments to increase their budgets as legal aid services produce genuine and tangible public cost savings. ${ }^{165}$ Therefore, it is imperative that remaining legal aid systems follow the example of England and Wales and complete a social return on investment study to estimate the preventative benefits legal aid has in their country by ensuring greater social justice.

\section{CONCLUSION}

A just society requires that its citizens have ability to access the law to ensure that their rights can be upheld and, where necessary, their responsibilities can be enforced so that justice can be achieved. As access to justice is not free and there is no equality of resources within society, some citizens will require aid to be able to enforce their rights or understand their responsibilities. Legal aid is thus an integral part of an ordered society where government is developing and implementing legal aid system supported by budget that hold the promise of effective realizing of subjective rights. Therefore, a carefully developed, implemented and evaluated legal aid budget is central to the realization of equal access to justice. Although government funding is important for sustainability of legal aid system, nowadays most governments tend to restrict the budget allocated to legal aid. Negative trend of legal aid funding is also followed by most generous legal aid systems (Norway, Netherlands and United Kingdom) whose budgets are in steady decline since 2012, which negatively affect on the number of cases eligible for civil legal aid and leaves citizens with unmet needs for information, support, advice and representation. A particular drop in legal aid budget allocations was observed in England and Wales where a large number of citizens remained without access to justice.

Regarding the budget cuts, Croatia is not an exception as it follows negative example of legal aid funding. Namely, Croatian legal aid system is far from

163 Cookson; Mold, op. cit. (fn. 146), p.1.

164 Ibid.; Farr, M.; Cressey, P.; Milner, S.; Abercrombie, N.; Jaynes, B., Proving the value of advice: a study of the impact of Citizens' Advice Bureau services, South West Forum, University of Bath, 2014., http://southwestforum.org.uk/advice-study (27 November 2017).

165 Cookson; Mold, op. cit. (fn. 146), p.1. 
being generous and funding is one of the crucial problems why system is non-functioning as the actual sums paid out for legal aid are practically insignificant. The trend of legal aid funding is also negative, as the legal aid budget, low from the very start, is constantly decreasing. ${ }^{166}$ That reflects on the number of granted cases, which is indicator that citizens with insufficient means can't seek remedies for the violations of rights that they have suffered. Negative impact of budget cuts reflects as well on distribution of primary legal aid as legal aid funds have been distributed to the secondary legal aid. Before 2014, funds available to the primary legal aid were ten times smaller than the funds available to the secondary legal aid. ${ }^{167}$ In 2015 the situation changed in favor of primary legal aid, but in 2016 legal aid budget returned to the level of funding that existed before 2014 when only $25 \%$ of the funds were available to the to the primary legal aid. ${ }^{168}$ From that point we can conclude that Croatian funding scheme still doesn't recognize overall importance of legal aid and specially preventative character of primary legal aid, which is first line of defense against complex legal problems for all citizens not only for those with insufficient means. It is a growing problem not only for the courts and government but also for the capacity of society to operate under the rule of law with citizens unable to access social entitlements and seek redress through the justice system. ${ }^{169}$

In generous legal aid systems and as well in Croatian legal aid system, funding is constantly decreasing. That requires from governments to change their policy regarding legal aid funding with an aim to prevent events that would be harmful and expensive for the larger society, such as domestic violence, long foster care stays, eviction, and health emergencies. Since lack of proper legal aid services has its focus on a budget cuts, the economics can't be ignored. Therefore, first step toward good legal aid policy is conducting empirical studies that could clearly indicate if generous funding of legal aid services saves money from state budget over time. Recently similar economic impact studies

\footnotetext{
166 The budget for legal aid provision is decreasing every year. The budget for legal aid provision is $72.05 \%$ lower in 2012 than in 2009 , while the costs for legal aid provision are rapidly increasing. See The Free Legal Aid Implementation Report, The European Union's IPA 2009 Programme for Croatia, Twinning Light Project HR/2009/IB/JH/03TL, "Improvement of free Legal Aid System", 2012, p. 99.

167 Preložnjak, B.; Brozović, J., Discouraging Unnecessary Litigation through the New Croatian Legal Aid System and Law Clinics, South Eastern Europe and the European Union - Legal Implications, Verlag Alma Mater, Saarbrücken, 2016, p. 112.

168 Ibid.

169 Loghan, G. L.; Sandbach, J., Justice in free fall - a report on the decline of civil legal aid in England and Wales, LAG special report, 2016-2017, http://www.lag.org.uk/media/278391/ december-january_lag_report.pdf (27 November 2017), p. 8.
} 
are conducted in England and Wales and they show that the return on the investment of funds in support of legal aid is significant as for $1 €$ spent in support of legal services $10 €$ are saved from state budget. Therefore, an allocation of funding for legal aid services should be a wise investment for state, as a small investment improves access to justice, strengthens communities and returns its value many fold. For all those reasons, financial support of legal aid must continue to be one of the government's priorities.

\section{LITERATURE:}

\section{BOOKS AND ARTICLES}

1. Abel, L., Vignola. S., Economic and Other Benefits Associated with the Provision of Civil Legal Aid, Seattle Journal for Social Justice, Vol. 9, No. 1, 2010, pp. 139-167.

2. Brouwers, J., et. al., Social Return On Investment: A practical guide for the development cooperation sector, Utrecht, 2010.

3. Cappelletti, M.; Garth, B., Access to Justice and the Welfare State: An introduction, u: Cappelletti, M. (ur.), Access to Justice and the Welfare State, Publications of the European University Institute, Alphen aan den Rijn, Sijthoff, 1981.

4. Dickson, B., The Legal System of Northern Ireland, SLS Legal Publications, 2005.

5. European judicial systems Edition 2014 (data 2012): Efficiency and quality of justice European Commission for the Efficiency of Justice (CEPEJ), Strasbourg, 2014.

6. European judicial systems Edition 2016 (data 2014): Efficiency and quality of justice European Commission for the Efficiency of Justice (CEPEJ), Strasbourg, 2016.

7. Farrow, T. C. W, What is access to justice?, Osgoode Hall Law Journal, Vol. 51, No. 3, pp. 957-987.

8. Farr, M.; Cressey, P.; Milner, S.; Abercrombie, N.; Jaynes, B., Proving the value of advice: a study of the impact of Citizens' Advice Bureau services, South West Forum, University of Bath, 2014.

9. Flyinn, A.; Hodgson, J., Access to Justice and Legal Aid Cuts: A Mismatch of Concepts in the Contemporary Australian and British Legal Landscape, u: Flyinn, A.; Hodgson, J., (ur.), Access to Justice and Legal Aid: Comparative Perspectives on Unmet Legal Need, Hart Publishing, Oxford, Portland and Oregon, 2016, pp. 1-21.

10. Goriely, T., Making the Welfare State Work:Changing Conception of Legal Remedies Whithin the British Welfare State, in: The Transformation of Legal Aid: Comparative and Historical Studies, Regan, F.; Paterson, A.; Goriely, T.; Fleming, D. (eds.), Oxford University Press, 2002, pp. 89-113. 
11. Jaynes, B., Proving the value of Advice Services in Devon: An impact study of the services provided by Citizens Advice Bureaux using Social Return on Investment, Citizens Advice Bureau, 2015.

12. Johnsen, J. T., Might Norway learn from Finnish legal aid? A comparison of legal aid in Norway and Finland - summary report, ILAG Conference "Delivering Effective Legal Aid Services Across Diverse Communities”, Wellington, 2009, pp. 1-27.

13. Johnsen, J. T.; Stawa, G.; Uzelac, A., Evaluation of the Croatian Legal Aid Act and its implementation (International Expertise), Zagreb, Oslo, Beč, 2010.

14. Magnuson, M. J., Frank, M. S., The High Cost of Efficiency: Courthouse Tech and Access to Justice, The Professional Lawyer, Vol. 22, No. 4, 2014, pp. 1-11.

15. Preložnjak, B., Besplatno informiranje i savjetovanje kao pretpostavka pristupa pravosuđu. Evaluacija uređenja u Hrvatskoj iz komparativne perspective, Zbornik Pravnog fakulteta u Zagrebu, Vol. 66, No. 6, 2016, pp. 721-742.

16. Preložnjak, B.; Brozović, J., Discouraging Unnecessary Litigation through the New Croatian Legal Aid System and Law Clinics, South Eastern Europe and the European Union - Legal Implications, Verlag Alma Mater, Saarbrücken, 2016, pp. 103-116.

17. Sallberg, Y.; Pollitowski, B., Civil Legal Aid: England \& Wales, Scotland and N Ireland compared, Briefing paper, no. 7603, House of Commons, 2016.

18. Uzelac, A.; Preložnjak, B., The Development of Legal Aid Systems in Western Balkans. A Study of Controversial Reforms in Croatia and Serbia, Kritisk Juss, Vol. 38, No. 3-4, 2012., pp. 261-287.

\section{LEGISLATION}

1. Free Legal Aid Act (LOV-1980-06-13-35, Lov om fri rettshjelp Rettshjelpsloven) from 13 June 1980 (in version from 1 July 2017, NL 2017-0099).

2. Legal Aid (Scotland) Act 1986, c. 47 from 25 July 1986 (in version from 25 November 2017, SI 1986/1358).

3. Legal Aid Act (Zakon o besplatnoj pravnoj pomoći, Narodne novine, No. 143/2013)

4. Legal Aid, Advice and Assistance (Northern Ireland) Order 1981 from 18. February 1981 (in version from 25. November 2017, SI 1981/228 (NI 8)).

5. Legal Aid, Sentencing and Punishment of Offenders Act 2012, c.10 from 1 May 2012 (in version from 25 November 2017, SI 2012/2906).

6. The Civil Legal Aid (Merits Criteria) (Amendment) Regulations 2016, SI 2016/781. 


\section{REPORTS}

1. Report on Exercising the Right to Legal Assistance and Expenditures in 2012, Zagreb, 2013.

2. Report on Exercising the Right to Legal Assistance and Expenditures in 2013, Zagreb, 2014.

3. Report on Exercising the Right to Legal Assistance and Expenditures in 2014, Zagreb, 2015.

4. Report on exercising the Right to Legal Assistance and Expenditures in 2016, Zagreb, 2017

\section{INTERNET PAGES}

1. Adjusted gross disposable income of households per capita in PPS, http:// ec.europa.eu/eurostat $/ \mathrm{tg} \mathrm{m} / \mathrm{table} . \mathrm{do} ? \mathrm{tab}=$ table \&plugin $=0 \&$ language $=\mathrm{en} \& \mathrm{p}-$ code $=$ tec00113 (10 November 2017).

2. Annex C: The Current Legal Aid Financial Eligibility Rules - Summary, https:// consult.justice.gov.uk/digital-communications/legal-aid-eligibility-and-universal-credit/supporting_documents/annexcsummaryofcurrentlegalaidfinancialeligibilityrules.pdf (22 November 2017).

3. A Sustainable Future for Legal Aid, The Scottish Government, Edinburgh, 2011, http://www.gov.scot/Resource/Doc/359686/0121521.pdf (7 November 2017).

4. Cookson, G.; Mold. F., The business case for social welfare advice services. An evidence review - lay summary, 2014., http://www.lag.org.uk/media/173260/julyaug_la_lowcommission.pdf (25 November 2017).

5. Byrnes, J., What's the True Value of Your Services? Use Social Return on Investment to Find Out.

6. Prove the worth of your organization's work with this process., http://www.csaco. org/files/70906026.pdf (27 November 2017),

7. Cuts that hurt: The impact of legal aid cuts in England on access to justice, Amnesty International UK, London, 2016, https://www.amnesty.org/en/documents/ eur45/4936/2016/en/ (25 November 2017).

8. Fylkesmannen utbetalte nesten 45 millioner til fri rettshjelp i 2016, https://www. fylkesmannen.no/Oslo-og-Akershus/Folk-og-samfunn/Fri-rettshjelp/Fylkesmannen-utbetalte-nesten-45-millioner-til-fri-rettshjelp-i-2016/ (15 November 2017).

9. How To: Calculate the social return on investment to make better decisions, http://www.mainebiz.biz/article/20160725/CURRENTEDITION/307209991/ how-to:-calculate-the-social-return-on-investment-to-make-better-decisions (25 November 2017). 
10. Hudson, A., Regeneration, Welfare State and Legal Aid, 1998, http://www. alastairhudson.com/legalsystem/legalaid\&welfarestate.pdf. (24 November 2017).

11. Legal aid, https://www.nidirect.gov.uk/articles/legal-aid (10 November 2017).

12. Legal Aid Agency Annual Report and Accounts 2012 to 2013, https://www.gov. uk/government/publications/legal-services-commission-annual-report-and-accounts-2012-to-2013 (7 November 2017).

13. Legal Aid Agency Annual Report and Accounts 2015 to 2016, https://www.gov. uk/government/publications/legal-aid-agency-annual-report-and-accounts-2015to-2016 (7 November 2017).

14. Legal Aid Agency Annual Report and Accounts 2016 to 2017, https://www.gov. uk/government/publications/legal-aid-agency-annual-report-and-accounts-2016to-2017 (7 November 2017).

15. Legal Aid in the Netherlands a broad outline - 2013, Raad voor Rechtsbijstand/ Legal Aid Board http://www.rvr.org/binaries/content/assets/rvrorg/informatieover-de-raad/brochure-legalaid_juni2013_webversie.pdf (10 November 2017),

16. Legal Aid in the Netherlands a broad outline - 2015, Raad voor Rechtsbijstand/ Legal Aid Board, http://www.rvr.org/binaries/content/assets/rvrorg/informatieover-de-raad/legalaid-brochure_online--2015.pdf (10 November 2017).

17. Legal Aid in the Netherlands a broad outline - 2017, Raad voor Rechtsbijstand/ Legal Aid Board, https://www.rvr.org/binaries/content/assets/rvrorg/informatieover-de-raad/12835_legalaid-brochure_2017.pdf (10 November 2017).

18. The legal aid impact test - assessing the implications of government proposals on courts and legal aid, http://www.courtsni.gov.uk/en-GB/S<afts5gwfervices/ LegalAid/LAImpactTest/ (25 November 2017).

19. Legal Aid Statistics in England and Wales, 2013-2014, https://www.gov.uk/government/statistics/legal-aid-statistics-april-2013-to-march-2014 (8 November 2017).

20. Legal Aid Statistics in England and Wales: October to December 2016, https:// www.gov.uk/government/statistics/legal-aid-statistics-october-to-december-2016 (7 November 2017).

21. Legal Assistance in Scotland fit for the 21st century, Law Society of Scotland, Discussion Paper, https://www.lawscot.org.uk/media/409526/legal-assistance-in-scotland-discussion-paper.pdf (7 November 2017).

22. Logan, R., Legal aid cuts are a major human rights issue, 2016, https://www. opendemocracy.net/openjustice/rachel-logan/amnesty-concludes-that-legal-aidcuts-are-major-human-rights-issue (24 November 2017).

23. Loghan, G. L.; Sandbach, J., Justice in free fall - a report on the decline of civil legal aid in England and Wales, LAG special report, 2016-2017, http:/www.lag. org.uk/media/278391/december-january_lag_report.pdf (27 November 2017). 
24. Managing legal aid, Northern Ireland Audit Office, 2016, http://www.niassembly. gov.uk/globalassets/committee-blocks/pac/niao-reports/managing-legal-aid-report.pdf (23 November 2017).

25. Peters, S., National report the Netherlands, Legal Aid in the Netherlands a broad outline, Legal Aid Bord 2016/2017, http://internationallegalaidgroup.org/images/ miscdocs/ILAG_2017_National_Report_-_The_Netherlands_-_Susanne_Peters. pdf (18 November 2017), Statistikk, https://www.rettsrad.no/ (10 November 2017).

26. Regional gross disposable household income (GDHI): 1997 to 2014, https:// www.ons.gov.uk/economy/regionalaccounts/grossdisposablehouseholdincome/ bulletins/regionalgrossdisposablehouseholdincomegdhi/2014 (22 November 2017).

27. Scottish Legal Aid Board Annual Report 2013-2014, http://www.slab.org. uk/common/documents/Annual_Report_2013_2014/SLAB_Annual_Report_2013-2014_-_Appendix_3_-_Civil_legal_assistance.pdf $\quad$ (7 November 2017).

28. Scottish Legal Aid Board Annual Report 2014-2015, http://www.slab.org.uk/export/sites/default/common/documents/Annual_report_2014_2015/SLAB_Annual_Report_2014-15_-_Appendix_3_-_Civil_legal_assistance.pdf (7 November 2017).

29. Scottish Legal Aid Board Annual Report 2016-2017, http://www.slab.org.uk/export/sites/default/common/documents/Annual_report_2016_17/SLAB_Annual_ Report_2016-17_Appendix_1_-_Key_Statistics_2016-17.pdf (7 November 2017).

30. Society launches survey on impact of legal aid, https://www.lawscot.org.uk/ news/2017/09/impact-of-legal-aid-survey/ (27 November 2017).

31. Towards a business case for legal aid, Paper to the Legal Services Research Centre's eighth international research conference, Citizens Advice, 2010, https:// www.accesstojusticeactiongroup.co.uk/wp-content/uploads/2011/07/towards_a_ business_case_for_legal_aid.pdf (27 November 2017).

32. User Guide to Legal Aid Statistics, England and Wales, Ministry of Justice statistics, 2017, https://www.gov.uk/government/uploads/system/uploads/attachment_data/file/623329/user-guide-to-legal-aid-statistics-in-england-and-walesjan-mar-17.pdf (7 November 2017),

33. What does legal aid cover?, https://scotland.shelter.org.uk/get_advice/advice_ topics/complaints_and_court_action/legal_costs/what_does_legal_aid_cover (7 November 2017).

34. Who can receive free legal aid, http://www.sivilrett.no/who-can-receive-free-legal-aid.307233.no.html (24 November 2017). 
